\title{
Upaya meningkatkan motivasi belajar dan pemahaman konsep IPA peserta didik dengan model pembelajaran problem posing
}

\author{
Irnin Agustina Dwi Astuti, Dasmo \\ Program Studi Pendidikan Fisika, Universitas Indraprasta PGRI \\ Jalan Raya Tengah No.80 Gedong, Pasar Rebo, Jakarta Timur \\ Surat-e: irnin.agustina@gmail.com
}

Tujuan penelitian ini adalah untuk mengetahui pengaruh model pembelajaran problem posing terhadap motivasi belajar dan pemahaman konsep IPA. Pembelajaran dengan model problem posing adalah pembelajaran yang menekankan peserta didik untuk membentuk atau mengajukan soal berdasarkan informasi atau situasi yang diberikan. Melalui penerapan model ini diharapkan dapat menjadi alternatif untuk meningkatkan motivasi belajar dan pemahaman konsep IPA peserta didik. Subyek penelitian ini adalah peserta didik SMP Negeri 7 Depok dengan sampel peserta didik kelas VIII-9 sebagai kelas eksperimen dan kelas VIII-8 sebagai kelas kontrol. Metode penelitian yang digunakan adalah metode quasi eksperimen dengan teknik analisis menggunakan uji Manova. Instrumen yang digunakan adalah angket motivasi belajar dan tes pemahaman konsep IPA setelah peserta didik diberikan perlakuan. Kelas eksperimen menggunakan model pembelajaran problem posing, sedangkan kelas kontrol menggunakan pembelajaran ceramah. Hasil penelitian yang diperoleh adalah: I) Terdapat pengaruh yang signifikan model pembelajaran terhadap motivasi belajar dan pemahaman konsep IPA. Hal ini dibuktikan oleh nilai Pillai's Trace, Wills' Lambda, Hotelling's Trace, dan Roy's largest Root sig sebesar 0,000 (<0,05). 2) Terdapat pengaruh yang signifikan model pembelajaran terhadap motivasi belajar IPA. Hal ini dibuktikan oleh hasil Manova yang memiliki nilai $F=143.844$ dengan sig $0,000(<0,05)$. 3) Terdapat pengaruh yang signifikan model pembelajaran terhadap pemahaman konsep IPA. Hal ini dibuktikan oleh hasil Manova di mana harga $F=7,197$, nilai $P$-value untuk kategori pemahaman konsep IPA (Y) adalah $0,000(<0,05)$.

The aim of the reserach was to determine the effect of the problem posing learning model of learning motivation and understanding of science concepts. Learning with models posing problem is learning that emphasize learners to form or ask questions based on the information or the given situation. Through the implementation of this model is expected to be an alternative to enhance learning motivation and understanding of science concepts learners. The subjects of this study are students of SMP Negeri 7 Depok with a sample of students in class VIII-9 as the experimental class and class VIII-8 as the control class. The method used is the method of quasi-experimental analysis techniques using MANOVA test. The instrument used was a questionnaire of learning motivation and test understanding of science concepts as learners are given treatment. Class experiments using problem posing learning model, while the control class using learning communicative. The results obtained are: I) There is a significant effect on the learning model of learning motivation and understanding of science concepts. This is evidenced by the value of Pillai's Trace, Wills' lambda, Hotelling's Trace, and Roy's Reviews largest Root sig of $0.000(<0.05)$. 2) There is significant influence learning model on motivation to learn science. This is evidenced by the results of Manova which has a value of $F$ $=\mathrm{I} 43844$ with sig $0.000(<0.05) .3)$ There is significant influence learning model to the understanding of science concepts. This is evidenced by the results of Manova in which the price of $\mathrm{F}=7.197$, $\mathrm{P}$-value for the category of understanding the concept of IPA $(\mathrm{Y})$ is 0.000 $(<0.05)$.

Kata kunci: motivasi belajar, pemahaman konsep, problem posing 


\section{Pendahuluan}

Mata pelajaran IPA merupakan salah satu mata pelajaran yang kurang menyenangkan bagi beberapa peserta didik, salah satunya yang terjadi di SMP N 7 Depok. Penyebabnya adalah peserta didik sukar membayangkan tujuan sebenarnya serta kejadian nyata dari belajar fisika. Padahal, semestinya aplikasi materi IPA sangat dekat dengan kehidupan sehari-hari. Beberapa masalah yang dihadapi peserta didik adalah pemahaman konsep dan motivasi belajar yang masih rendah. Banyak peserta didik masih belum memahami konsep IPA secara benar. Kondisi ini ditunjukkan dengan seringnya mengalami kegagalan dalam mengerjakan soal-soal IPA yang menuntut jawaban divergen. Mereka cenderung menjawab pertanyaan hanya dengan menggunakan satu cara saja atau sesuai dengan yang dicontohkan guru tanpa berusaha untuk mencari alternatif jawaban yang berbeda.

Salah satu komponen penting yang dapat menentukan keberhasilan peserta didik dalam mengikuti proses pembelajaran adalah guru. Seorang guru dituntut tidak hanya mampu menguasai ilmu dan pengetahuan tentang materi yang hendak diajarkan. Akan tetapi, kemampuan dalam menggunakan model pembelajaran di kelas juga merupakan kemampuan dasar yang wajib dikuasai. Penggunaan model pembelajaran yang tepat dapat menentukan keberhasilan peserta didik dalam memahami materi yang disampaikan dengan baik.

Kelemahaman yang selama ini sering kali terjadi adalah guru masih menggunakan pembelajaran satu arah yaitu dari guru ke peserta didik. Guru lebih mendominasi pembelajaran sehingga pembelajaran cenderung monoton dan mengakibatkan peserta didik merasa jenuh dan bosan. Oleh karena itu dalam memberikan materi kepada peserta didik, guru hendaknya menggunakan berbagai variasi pendekatan, strategi, maupun model yang sesuai dengan situasi sehingga tujuan pembelajaran yang direncanakan akan tercapai. Perlu diketahui bahwa baik atau tidaknya suatu pemilihan model pembelajaran akan tergantung tujuan pembelajarannya, kesesuaian dengan materi pembelajaran, tingkat perkembangan peserta didik, kemampuan guru dalam mengelola pembelajaran serta mengoptimalkan sumber-sumber belajar yang ada.

Salah satu model pembelajaran yang inovatif yang dapat diterapkan dalam pembelajaran IPA untuk mengembangkan kemampuan pemahaman konsep IPA adalah menggunakan pendekatan problem posing. Pembelajaran dengan model problem posing adalah pembelajaran yang menekankan peserta didik untuk membentuk atau mengajukan soal berdasarkan informasi atau situasi yang diberikan. Informasi yang ada diolah dalam pikiran dan setelah dipahami, maka peserta didik akan bisa mengajukan pertanyaan. Dengan adanya tugas pengajuan soal (problem posing) akan menyebabkan terbentuknya motivasi belajar yang baik dan pemahaman konsep yang lebih mantap pada diri peserta didik terhadap materi yang telah diberikan. Kegiatan itu akan membuat peserta didik lebih aktif dan kreatif dalam membentuk pengetahuannya dan pada akhirnya pemahaman peserta didik terhadap konsep IPA lebih baik lagi. Berdasarkan kondisi tersebut, penelitian ini dilakukan sebagai upaya untuk meningkatkan motivasi belajar dan pemahaman konsep IPA peserta didik melalui model pembelajaran problem posing.

\section{Kajian Pustaka}

Model pembelajaran problem posing mewajibkan peserta didik untuk mengajukan soal sendiri melalui belajar soal dengan mandiri. Model pembelajaran problem posing adalah suatu model pembelajaran yang mewajibkan para peserta didik untuk mengajukan soal sendiri melalui belajar soal (berlatih soal) secara mandiri ${ }^{[1]}$. Problem posing dapat membantu peserta didik dalam mencari topik baru dan menyediakan pemahaman yang lebih mendalam. Selain itu, problem posing dapat mendorong terciptanya ide-ide baru yang berasal dari setiap topik yang diberikan.

Penerapan suatu model pembelajaran harus memiliki langkah-langkah yang jelas, hal tersebut sangat berpengaruh terhadap kinerja pendidik dan aktivitas yang dilakukan peserta didik. Langkah-langkah model pembelajaran problem posing yaitu I) pendidik menjelaskan materi pelajaran atau disertai dengan alat peraga secara singkat, 2) memberikan latihan soal secukupnya, 3) peserta didik mengajukan soal yang menantang dan dapat menyelesaikan (dilakukan secara kelompok), 4) Kelompok lain mengerjakan soal yang sudah dibuat dan menanggapinya 4) pendidik meminta peserta didik menyajikan soal temuan di depan kelas, dan 5) guru memberikan penguatan dan tugas rumah secara individual ${ }^{[2]}$.

Problem posing adalah model pembelajaran yang melibatkan peserta didik dalam proses pembelajaran secara langsung untuk memberi kesempatan kepada peserta didik dalam menganalisis permasalahan yang ada dengan serangkaian kegiatan-kegiatan yang lebih bermakna. Pembelajaran problem posing memiliki ciri-ciri sebagai berikut, I) guru belajar dari murid dan murid belajar dari guru, 2) guru menjadi rekan murid yang melibatkan diri dan menstimulasi daya pemikiran kritis murid-muridnya serta mereka saling memanusiakan, 3) manusia dapat mengembangkan kemampuannya untuk mengerti secara kritis dirinya dan dunia tempat ia berada, dan 4) pembelajaran problem posing senantiasa membuka rahasia realita yang menantang manusia kemudian menuntut suatu tanggapan terhadap tantangan tersebut ${ }^{[1]}$.

Sementara itu, motivasi adalah daya penggerak aktif seseorang yang bersifat intrinsik untuk melakukan suatu 
tindakan guna mencapai tujuan atau memenuhi kebutuhan $^{[3]}$. Motivasi merupakan proses yang memberikan energi, mengarahkan, dan mempertahankan perilaku. Hal ini berarti bahwa konsep motivasi digunakan untuk menjelaskan keinginan berperilaku, arah perilaku (pilihan), intensitas perilaku (usaha, berkelanjutan), dan penyelesaian atau prestasi yang sesungguhnya ${ }^{[4]}$.

Dalam kegiatan belajar, maka motivasi dapat dikatakan sebagai keseluruhan daya penggerak di dalam diri peserta didik yang menimbulkan kegiatan belajar, yang menjamin kelangsungan dari kegiatan belajar dan memberikan arah pada kegiatan belajar, sehingga tujuan yang dikehendaki oleh subjek belajar itu dapat tercapai ${ }^{[5]}$. Dalam proses mengajar, hal terpenting adalah pencapaian pada tujuan yaitu agar peserta didik mampu memahami sesuatu berdasarkan pengalaman belajarnya. Kemampuan pemahaman ini merupakan hal yang sangat fundamental, karena dengan pemahaman akan dapat mencapai pengetahuan prosedur. Pemahaman merupakan bagian dari ranah kognitif yang berkenaan dengan hasil belajar intelektual dan lebih tinggi tingkatannya di banding pengetahuan. Pemahaman merupakan landasan bagi peserta didik untuk membangun wawasan ${ }^{[6]}$. Dalam pembelajaran IPA lebih menekankan pada konsep. Artinya dalam mempelajari IPA peserta didik harus memahami konsep IPA terlebih dahulu agar dapat menyelesaikan soal-soal dan mampu mengaplikasikan pembelajaran tersebut dalam dunia nyata.

\section{Metode Penelitian/Eksperimen}

Penelitian ini dilaksanakan di SMP Negeri 7 Depok pada bulan Juli - Agustus 2016. Metode penelitian yang digunakan pada penelitian ini adalah metode quasi eksperimen dengan teknik analisis menggunakan uji MANOVA. Hal ini dikarenakan ada 2 kelompok yang dibandingkan/diberikan perlakuan yang berbeda tanpa mengubah komposisi kelompok tersebut. Populasi dalam penelitian ini adalah seluruh peserta didik di SMP N 7 Depok. Sedangkan sampel dalam penelitian ini adalah peserta didik kelas VIII-8 sebagai kelas kontrol sebanyak 34 peserta didik dengan pembelajaran ceramah dan peserta didik kelas VIII-9 sebagai kelas eksperimen sebanyak 43 soal dengan model pembelajaran problem posing.

Dalam penelitian ini terdapat dua variabel, yaitu variabel bebas $(\mathrm{X})$ adalah model pembelajaran problem posing dan variabel terikat $(\mathrm{Y})$ adalah motivasi belajar dan pemahaman konsep IPA peserta didik. Adapun desain penelitian diperlihatkan pada gambar berikut ini.
Tabel I. Paradigma penelitian

\begin{tabular}{cccc}
\hline \multicolumn{4}{c}{ Model Pembelajaran } \\
\hline \multicolumn{4}{c}{ Problem Posing } \\
$\left(A_{\mathrm{I}}\right)$ & \multicolumn{2}{c}{$\begin{array}{c}\text { Ceramah } \\
\left(A_{2}\right)\end{array}$} \\
\hline Motivasi & Pemahaman & Motivasi Belajar & Pemahaman \\
Belajar $\left(Y_{\mathrm{I}}\right)$ & Konsep $\left(Y_{2}\right)$ & $\left(Y_{\mathrm{I}}\right)$ & Konsep $\left(Y_{2}\right)$ \\
\hline$Y_{\mathrm{I}} A_{\mathrm{I}}$ & $Y_{2} A_{\mathrm{I}}$ & $Y_{\mathrm{I}} A_{2}$ & $Y_{2} A_{2}$ \\
\hline
\end{tabular}

Penelitian ini menggunakan 2 instrumen yaitu angket untuk mengumpulkan data motivasi belajar dan tes untuk mendapatkan data pemahaman konsep IPA. Instrumen tes pemahaman konsep (postest) disusun untuk mendapatkan data mengenai pemahaman konsep IPA dalam pemecahan masalah IPA setelah perlakuan. Selanjutnya, uji persyaratan analisis terdiri atas normalitas dan homogenitas. Dalam analisis data penelitian ini menggunakan SPSS versi 16.0 dengan uji Manova. Multivariate Analysis of Variance (Manova) adalah analisis kovarian dimana setidaknya ada dua variabel dependen yang diukur secara simultan untuk menguji apakah terdapat perbedaan perlakuan terhadap sekelompok variabel dependen ${ }^{[7]}$. Dalam penelitian ini variabel bebas yang digunakan yaitu model pembelajaran problem posing, variabel terikat yaitu motivasi belajar dan pemahaman konsep IPA.

\section{Hasil Penelitian dan Pembahasan}

Setelah dilakukan uji normalitas dan homogenitas dan hasilnya menunjukkan bahwa sampel penelitian berasal dari populasi berdistribusi normal dan varians sampel homogen, maka pengujian hipotesis dengan menggunakan Manova dapat dilakukan. Analisis terhadap data pemahaman konsep peserta didik dilakukan dengan menggunakan Manova yang proses perhitungannya dibantu dengan program SPSS 16.0. dapun ringkasan hasil analisis data dengan menggunakan Manova dapat dilihat pada tabel berikut ini:

Tabel 2. Hasil uji manova dengan SPSS

\begin{tabular}{|c|c|c|c|c|c|c|}
\hline \multicolumn{7}{|c|}{ Multivariate Tests ${ }^{\mathrm{b}}$} \\
\hline Effect & & Value & $\mathrm{F}$ & $\begin{array}{l}\text { Hypoth } \\
\text { esis df }\end{array}$ & Error $\mathrm{df}$ & Sig. \\
\hline \multirow{4}{*}{ Intercept } & Pillai's Trace & .997 & I. $553 \mathrm{E} 4^{\mathrm{a}}$ & 2.000 & 80.000 & .000 \\
\hline & Wilks' Lambda & .003 & I. $.553 \mathrm{E} 4^{\mathrm{a}}$ & 2.000 & 80.000 & .000 \\
\hline & Hotelling's Trace & 388.227 & I. $553 \mathrm{E} 4^{\mathrm{a}}$ & 2.000 & 80.000 & .000 \\
\hline & $\begin{array}{l}\text { Roy's Largest } \\
\text { Root }\end{array}$ & 388.227 & I. $.553 \mathrm{E} 4^{\mathrm{a}}$ & 2.000 & 80.000 & .000 \\
\hline \multirow{4}{*}{$\begin{array}{l}\text { model_pe } \\
\text { mbelajaran }\end{array}$} & Pillai's Trace & .718 & I. $020 \mathrm{E} 2^{\mathrm{a}}$ & 2.000 & 80.000 & .000 \\
\hline & Wilks' Lambda & .282 & I.020E $2^{\mathrm{a}}$ & 2.000 & 80.000 & .000 \\
\hline & Hotelling's Trace & 2.549 & I. $.020 \mathrm{E} 2^{\mathrm{a}}$ & 2.000 & 80.000 & .000 \\
\hline & $\begin{array}{l}\text { Roy's Largest } \\
\text { Root }\end{array}$ & 2.549 & I.020E $2^{\mathrm{a}}$ & 2.000 & 80.000 & .000 \\
\hline
\end{tabular}


Berdasarkan data di atas, maka hipotesis yang diajukan dapat terjawab. Adapun penjelasan mengenai pembahasannya adalah sebagai berikut.

Hipotesis Pertama: terdapat pengaruh yang signifikan model pembelajaran terhadap motivasi belajar dan pemahaman konsep IPA secara multivariat. Berdasarkan hasil pengujian yang terdapat pada tabel Multivariate Test pada uji statistik terdapat nilai Pillai's Trace, Wills' Lambda, Hotelling's Trace, dan Roy's largest Root sig sebesar 0,000 $(<0,05)$. Hal ini menunjukkan terdapat pengaruh yang signifikan model pembelajaran terhadap pemahaman konsep dan motivasi belajar IPA.

Hipotesis kedua: terdapat pengaruh yang signifikan model pembelajaran terhadap motivasi belajar. Berdasarkan hasil pengujian pada tabel Test of BetweenSubject Effects diketahui untuk kategori pemecahan masalah (Y2) memiliki nilai $\mathrm{F}=\mathrm{I} 43,844$ sig 0,000 $(<0,05)$. Dengan demikian hipotesis nol ditolak atau terdapat perbedaan yang signifikan antara motivasi belajar IPA pada kelompok peserta didik kelompok kelas eksperimen dengan kelompok kelas kontrol. Sehingga disimpulkan terdapat pengaruh yang signifikan model pembelajaran terhadap motivasi belajar IPA.

Hipotesis ketiga: terdapat pengaruh yang signifikan model pembelajaran terhadap pemahaman konsep IPA. Berdasarkan hasil pengujian pada tabel Test of BetweenSubjest Effects diketahui nilai $F=117,899$, nilai $P$-value untuk kategori pemahaman konsep IPA (YI) adalah $0,000(<0,05)$. Dengan demikian hipotesis nol ditolak atau terdapat perbedaan yang signifikan antara pemahaman konsep IPA pada kelompok kelas eksperimen dengan kelompok kelas kontrol. Sehingga dapat disimpulkan terdapat pengaruh yang signifikan model pembelajaran terhadap pemahaman konsep IPA.

Penelitian ini mendukung teori bahwa model pembelajaran problem posing memiliki pengaruh yang signifikan terhadap motivasi belajar dan dan pemahaman konsep IPA. Pemahaman konsep IPA pada penelitian ini adalah kemampuan kemampuan peserta didik dalam menguasai materi pokok gerak pada benda. Pemahaman konsep sangat penting, karena dengan penguasaan konsep akan memudahkan peserta didik dalam mempelajari materi IPA. Pada setiap pembelajaran diusahakan lebih ditekankan pada penguasaan konsep agar peserta didik memiliki bekal dasar yang baik untuk mencapai kemampuan dasar yang lain seperti penalaran, komunikasi, koneksi dan pemecahan masalah.

Banyak model pembelajaran yang bisa diterapkan untuk mengatasi berbagai masalah proses pembelajaran tetapi model pembelajaran yang tepat untuk diterapkan untuk mengatasi masalah ini adalah suatu sistem pembelajaran yang lebih memperhatikan aspek peserta didik. Salah satunya adalah pembelajaran dengan model pembelajaran problem posing. Model pembelajaran problem posing merupakan salah satu bentuk kegiatan dalam pembelajaran fisika yang dapat mengaktifkan peserta didik, mengembangkan kemampuan berfikir peserta didik dalam menyelesaikan masalah serta menimbulkan sikap positif terhadap materi IPA. Membiasakan peserta didik dalam merumuskan, menghadapi dan menyelesaikan soal merupakan salah satu cara untuk mencapai penguasaan suatu konsep ${ }^{[8]}$.

Model pembelajaran dalam pemahaman konsep dan motivasi belajar IPA sangat berpengaruh pada peserta didik. Model pembelajaran Problem Posing ini dirancang agar peserta didik dapat aktif dan menganalisis suatu masalah secara mandiri, dapat membuat pertanyaan dan mengerjakan sendiri. Guru perlu menekankan pada peserta didik pada saat pembelajaran yaitu pertanyaan yang dibuat masing-masing peserta didik merupakan suatu masalah atau kendala yang dialami peserta didik.

Sedangkan model pembelajaran konvensional adalah model pembelajaran yang cara penyampaian materi di kelas dengan metode ceramah. Model pembelajaran konvensional lebih berpusat pada guru, sehingga peserta didik kurang aktif dalam pembelajaran di kelas. Peserta didik hanya mendengarkan penjelasan guru yang terkadang membuat jenuh peserta didik sehingga motivasi belajar peserta didik juga menurun.

Keadaan peserta didik antara kelas eksperimen dengan kelas kontrol terlihat sangat berbeda ketika di kelas. Di kelas eksperimen yang menggunakan pembelajaran problem posing peserta didik sangat antusias dalam belajar IPA. Materi yang dibahas mengenai konsep Gerak. Materi gerak peserta didik dituntut untuk memahami konsep yang ada, tidak hanya sekedar menghafal rumus, karena dalam materi gerak terdapat banyak rumus fisika.

Peserta didik aktif berdiskusi dan bertanya jika belum paham materinya, peserta didik juga secara mandiri mencari tahu solusi permasalahan yang diberikan oleh guru kemudian langsung didiskusikan dengan teman sekelompoknya. Setelah itu peserta didik membuat soal atau pertanyaan dan menjawabnya sendiri. Setelah semua kelompok sudah selesai melaksanakan tugasnya, kemudian guru memberikan soal-soal yang dibuat oleh peserta didik secara acak ke kelompok lain untuk dikerjakan. Peserta didik dari kelompok lain juga antusias mencari tahu jawaban dari soal tersebut. Akhir dari kegiatan pembelajaran guru menunjuk beberapa kelompok untuk maju ke depan kelas mempresentasikan hasil diskusi dan jawaban mereka. Kelompok yang bisa menjawab tanggapan dari kelompok lain diberi hadiah atau reward dari guru, untuk menambah motivasi belajar peserta didik. Setelah dianalisis kegiatan pembelajaran yang sudah dilakukan diperoleh bahwa motivasi belajar IPA peserta didik sangat tinggi. Motivasi belajar IPA peserta didik ini akan mempengaruhi hasil belajar peserta didik.

Sedangkan pembelajaran di kelas kontrol, peserta didik terlihat pasif dan kurang antusias mengikuti pembelajaran, karena guru hanya ceramah menjelaskan materinya saja. 
Sehingga membuat peserta didik jenuh dan bosan belajar di kelas. kenyataan ini membuat motivasi belajar IPA peserta didik di kelas kontrol menurun, sehingga akan berdampak pada hasil belajar IPA peserta didik juga rendah.

\section{Kesimpulan}

Adapun kesimpulan yang dapat diambil dari penelitian ini berdasarkan hasil pengujian hipotesis dan pembahasan hasil penelitian adalah sebagai berikut:

I. Terdapat pengaruh yang signifikan model pembelajaran terhadap pemahaman konsep IPA dan motivasi belajar IPA secara multivariate. Berdasarkan hasil pengujian yang terdapat pada tabel Multivariate Test pada uji statistik terdapat nilai Pillai’s Trace, Wills' Lambda, Hotelling's Trace, dan Roy's largest Root sig sebesar 0,000 $(<0,05)$.

2. Terdapat pengaruh yang signifikan model pembelajaran terhadap motivasi belajar IPA. Hal ini berdasarkan perhitungan skor motivasi belajar IPA peserta didik yang diajar dengan model pembelajaran Problem Posing (kelompok eksperimen) dengan menggunakan SPSS I6.0 diperoleh nilai rerata skor 95,84; sedangkan yang dengan menggunakan model pembelajaran Konvensional diperoleh nilai rerata 83,60. Perbedaan hasil motivasi belajar IPA di antara kedua kelompok ini adalah perbedaan yang signifikan. Ini ditunjukkan oleh hasil MANOVA dimana memiliki nilai $F=143.844$ dengan sig $0,000(<0,05)$.

3. Terdapat pengaruh yang signifikan model pembelajaran terhadap pemahaman konsep IPA. Hal ini berdasarkan pada hasil analisis peserta didik yang diberi model pembelajaran Problem Posing memiliki rerata hasil belajar sebesar 76 dan rerata hasil belajar peserta didik yang diberi model pembelajaran Konvensional sebesar 56. Perbedaan hasil pemahaman konsep kimia di antara kedua kelompok ini adalah perbedaan yang signifikan. Ini ditunjukkan oleh hasil MANOVA di mana harga $\mathrm{F}$ $=7,197$, nilai P-value untuk kategori pemahaman konsep IPA (YI) adalah 0,000 $(<0,05)$..

\section{Ucapan Terimakasih}

Kami ucapkan terimakasih kepada Kepala Sekolah SMP N 7 Depok yang telah memberikan ijin untuk melaksanakan penelitian di SMP N 7 Depok.

\section{Kepustakaan}

[I] Herawati, Oktiana Dwi Putra; Rusdy Siroj; H.M.Djahir Basir. 2013. Pengaruh Pembelajaran Problem Posing Terhadap Kemampuan Pemahaman Konsep Matematika Siswa Kelas XI
IPA SMA Negeri 6 Palembang. Jurnal Pendidikan Matematika volume 4. No.I Juni 2010.

[2] Huda, Miftahul. 2015. Model-Model Pengajaran dan Pembelajaran. Yogyakarta: Pustaka Pelajar.

[3] Surahmadi, Bambang. 2015. Pengaruh Model Pembelajaran POE (Predict-Observe-Explain) Ditinjau Dari Motivasi Belajar Dan Pengetahuan Awal Terhadap Hasil Belajar IPA Peserta Didik Kelas VII SMP N I Temanggung. Prosiding Pertemuan IImiah XXIX HFI Jateng \& DIY, Yogyakarta, 25 April 2015 ISSN : 0853-0823.

[4] Santrock, John W. 20I4. Psikologi Pendidikan. Jakarta: Salemba Humanika.

[5] Sardirman. 2012. Interaksi dan Motivasi Belajar Mengajar. Jakarta: Rajawali Pers.

[6] Simanjuntak, Mariati Purnama. 2012. Peningkatan Pemahaman Konsep Fisika Mahasiswa Melalui Pendekatan Pembelajaran Pemecahan Masalah Berbasis Video. Jurnal Pendidikan Fisika ISSN 2252-732X Vol. I No. 2 Desember 2012. http://dikfispasca.org/wp-content/uploads/ 2013/ 04/Artikel- Mariati-Purnama-S.-55-60.pdf. Diunduh tanggal 20 Mei 2016

[7] Surya, 2013. Manova dan Manacova dalam Statistik. http://wawasanedukasi.blogspot.co.id/20I4/I2/manova-danmancova-dalam-statistik.html. Diakses tanggal 20 Februari 2016.

[8] Sriwenda, Bakti Mulyani, Sri Yamtinah. 2013. Penerapan Pembelajaran Model Problem Posing Untuk Meningkatkan Kreativitas Dan Prestasi Belajar Siswa Pada Materi Laju Reaksi Kelas XI IPA 5 SMA Negeri I Boyolali Tahun Pelajaran 2012/2013. Jurnal Pendidikan Kimia (JPK), Vol. 2 No. 2 Tahun 2013 Program Studi Pendidikan Kimia Universitas Sebelas Maret. 
Upaya meningkatkan motivasi belajar dan pemahaman konsep IPA peserta didik dengan model pembelajaran problem posing 